\title{
intermational review of
}




\section{International Review of Social History}

PUBLISHED FOR THE INTERNATIONAAL INSTITUUT VOOR SOCIALE

GESCHIEDENIS, AMSTERDAM

Executive Editor

Marcel van der Linden, Internationaal Instituut voor Sociale Geschiedenis, Cruquiusweg 31, 1019 AT Amsterdam, The Netherlands

\section{Editorial Committee}

Bert Altena, Karel Davids, Angelique Janssens, Jan Lucassen, Leo van Rossum, Willem van Schendel, Fritjof Tichelmann, Erik Zürcher

\section{Editorial Assistants}

Aad Blok, Mona Hilfman

\section{Advisory Board}

Shahid Amin, University of Delhi Peter C. Gutkind, University of Wanvick Hartmut Kaclble, Humboldt-Universitat zu Beslin David Montgomery, Yale University Ian Roxborough, State University of New York John Saville, University of Hull Jurgen Schlumbohm, Max-PlanckInstitut für Geschichte, Göttingen Charles Tilly, New School for Social Research, New York Patrick Fridenson, EHESS, Paris.

\section{Subscriptions}

International Review of Social History (ISSN 0020-8590) is published in three parts in April, August and December plus one supplement in December. Three parts plus one supplement form a volume. The subscription price (excluding VAT) of volume 39 (1994) (which includes postage) is $£ 52$ net (US\$89 in the USA, Canada and Mexico) for institutions; $£ 33$ net (US\$49 in the USA, Canada and Mexico) for individuals ordering direct from the publisher and certifying that the journal is for their own personal use. Single parts and the supplement are $£ 14$ (US\$24 in the USA, Canada and Mexico) plus postage. EU subscribers (outside the UK) who are not registered for VAT should add VAT at their country's rate. VAT registered subscribers should provide their VAT registration number. Japanese prices for institutions are available from Kinokuniya Company Ltd, P.O. Box 55, Chitose, Tokyo.

A cumulative index to volumes $1-37$ is available separately at $£ 10$ net ( $\$ 19$ in the US $\dot{A}$, Canada and Mexico).

Orders, which must be accompanied by payment, may be sent to a bookseller, subscription agent or direct to the publisher: Cambridge University Press, The Edinburgh Building, Shaftesbury Road, Cambridge CB2 2RU; or in the USA, Canada and Mexico: Cambridge University Press, 40 West 20th Street, New York, NY 10011-4211. Copies of the journal for subscribers in the USA, Canada and Mexico are sent by air to New York to arrive with minimum delay. Second class postage paid at New York, NY and at additional mailing offices. Postmaster: send address changes in USA, Canada and Mexico to International Review of Social History, Cambridge University Press, 110 Midland Avenue, Port Chester, New York, NY 10573-4930.

\section{Copying}

This journal is registered with the Copyright Clearance Center, 222 Rosewood Drive, Danvers, MA 01923, USA. Organizalions in the USA who are also registered with the C.C.C. may therefore copy material (beyond the limits permitted by sections 107 and 108 of U.S. Copyright law) subject to payment to the C.C.C. of the per copy fee of 505.00 . This consent does not extend to multiple copying for promotional or commercial purposes. Code 0020-8590/94. ISI Tear Sheet Service, 3501 Market Street, Philadelphia, PA 19104, USA, is authorized to supply single copies of separate articles for private use only. Organizations authorised by the Copyright Licensing Agency may also copy material subject to the usual conditions. For all other use, permission should be sought from Cambridge or from the American Branch of Cambridge University Press. 